\title{
PENGARUH MODEL PROBLEM BASED LEARNING TERHADAP HIGHER ORDER THINGKING SKILLS (HOTS) MATEMATIS SISWA
}

\author{
Hodiyanto \\ Program Studi Pendidikan Matematika, Fakultas MIPATEK, IKIP PGRI Pontianak \\ hodiyanto@ikippgriptk.ac.id
}

\begin{abstract}
The general objective of this study was to determine the effect of the Problem Based Learning model on the students' Higher Order Thingking Skills (HOTS) in the material of system of two-variable linear equations in class $\mathrm{X}$ of SMA Negeri 9 Pontianak. The specific objectives are (1) to find out the mathematical Higher Order Thingking Skills (HOTS) before and after applied Problem Based Learning in the material of system of two variable linear equations in class X of SMA Negeri 9 Pontianak. (2) to determine the effect and influence of the Problem Based Learning model on students' Higher Order Thingking Skills (HOTS) in the material of system of two-variable linear equations in class X of SMA Negeri 9 Pontianak. The method used in this study is an experiment, with a Pre-Experimental Design research form. The design in this study is One Group Pretest-Posttest Design, which uses only one sample group given the initial test and final test after being given treatment. Based on the results of data analysis conducted on the findings in the field, the results of this study indicate that there is an influence of the Problem Based Learning model on mathematical students' Higher Order Thingking Skills (HOTS) in the two-variable linear equation system material in class X Pontianak State High School 9.
\end{abstract}

Keywords: Problem Based Learning, Higher Order Thingking Skills, experiment.

\section{PENDAHULUAN}

Matematika adalah salah satu mata pelajaran yang sangat dibutuhkan dalam kehidupan bermasyarakat. Oleh sebab itu, mata pelajaran ini sudah diajarkan mulai tingkat sekolah dasar sampai sekolah menengah atas bahkan sampai ke perguruan tinggi. Tetapi fakta di lapangan menunjukkan bahwa matematika masih menjadi momok di kalangan peserta didik. Hal ini menajadi pekerjaan yang tidak mudah bagi seorang pendidik/guru maupun dosen bagaimana agar asumsi bahwa matematika itu sulit dan menjadi momok bagi peserta didik bisa menjadi sebaliknya, artinya bagaimana agar peserta didik berpikir bahwa belajar matematika itu menyenangkan dan tidak sulit.

Pada umumnya proses pembelajaran matematika yang ada di sekolah lebih menekankan pada kemampuan siswa untuk menghafal dan mengaplikasikan konsep matematika, artinya masih fokus pada peningkatan kemampuan berpikir tingkat rendah siswa dan masih jarang mengembangkan/memperbaiki kemampuan berpikir tingkat tinggi peserta didiknya, sehingga kemampuan berpikir tingkat tinggi peserta didik masih tergolong rendah.

Pembelajaran matematika memiliki posisi yang sangat urgensi dalam mencapai tujuan pendidikan. Tujuan pembelajaran matematika adalah untuk (1) menumbuhkan dan mengembangkan keterampilan berhitung, (2) Menumbuhkan kemampuan siswa yang dapat dialihgunakan melalui kegiatan matematika, (3) mengembangkan pengetahuan dasar matematika sebagai bekal melanjutkan ke SMA dan Perguruan tinggi, dan (4) membuat sikap logis, kritis, cermat dan disiplin (Depdinas, 2006). Salah satu karakteristik matematika adalah mempunyai objek yang bersifat abstrak. Sifat abstrak ini menyebabkan banyak siswa mengalami kesulitan dalam matematika. Salah satu kompetensi yang ditekankan untuk lulusan siswa SMA dalam pembelajaran matematika adalah menunjukkan sikap logis, kritis, analitis, kreatif cermat dan teliti, bertanggung jawab, responsif, dan tidak mudah menyerah 
dalam menyelesaikan masalah (Permendikbud Nomor 59, 2014).

Menurut Permendikbud 22 Tahun 2006 yang menyatakan bahwa mata pelajaran matematika diberikan kepada semua peserta didik untuk membekali mereka dengan kemampuan berpikir logis, analitis, sistematis, kritis, dan kreatif, serta kemampuan bekerja sama. Fokus utama tujuan pembelajaran matematika dan tuntutan kurikulum 2013 adalah mengembangkan Higher Order Thinking Skills (HOTS) siswa. HOTS adalah kemampuan berpikir tingkat tinggi yaitu analisis, evaluasi, dan mengkreasi. HOTS juga merupakan aspek yang sangat penting untuk dikembangkan dalam pembelajaran matematika karena dalam menyelesaikan permasalahan yang tidak rutin siswa memerlukan HOTS. Kemampuankemampuan ini merupakan kemampuan berpikir level atas pada Taksonomi Bloom yang terbaru hasil revisi oleh Anderson dan Krathwohl (Krathwohl, 2002). Lebih lanjut Krathwohl (2002) menyebutkan/bahwa indikator kemampuan befikir tingkat tinggi dan juga yang digunakan dalam penelitian ini adalah sebagai berikut:

(1) Analyze (menganalisis) yaitu memecahkan permasalahan menjadi bagian-bagian penyusunnya dan mendeteksi bagaimana bagian-bagian tersebut saling berhubungan. (2) Evaluate (mengevaluasi) yaitu Membuat penilaian berdasarkan kriteria dan standar yang telah dibuat sebelumnya. (3) Create (mencipta) yaitu Menempatkan elemen-elemen untuk membentuk sesuatu yang baru atau asli.

Rendahnya kemampuan berpikir tingkat tinggi peserta didik Indonesia juga dapat dilihat dari hasil Programme Internationale for Student Assessment (PISA) tahun 2015, Indonesia berada pada peringkat 69 dari 72 negara peserta. Assessment framework dalam PISA lebih menekankan pada kemampuan bernalar, memecahkan masalah, berargumentasi, dan berkomunikasi berdasarkan pada kemampuan berpikir tingkat tinggi. Pentingnya peserta didik dilatih untuk berpikir tingkat tinggi adalah agar peserta didik dapat menganalisis, mengevaluasi, dan mengkreasi serta memahami informasi, berpikir yang berkualitas akan

mencapai hasil akhir yang berkualitas sehingga peserta didik menjadi lebih mandiri. Semakin baik kemampuan berpikir tingkat tinggi peserta didik akan berdampak baik terhadap hasil belajarnya.

Berdasarkan hasil penelitian sebelumnya yang dilakukan oleh Ayuningtias (2013) dan Prasetyani, Hartono \& Susanti (2016) mengatakan bahwa kemampuan berpikir tingkat tinggi tegolong masih rendah. Selain itu, peneliti juga melakukan pra observasi untuk memperkuat masalah yang akan dipecahkan. Pada saat pra observasi, peneliti memberikan soal untuk mengetahui kemampuan berpikir tingkat tinggi siswa. Dilihat dari hasil pra observasi, proses penyelesaian soalnya masih kurang dalam memahami masalah yang diberikan, belum bisa membedakan bagian yang relevan dan bagian yang tidak relevan, dan masih kurang dalam menghubungkan apa yang diketahui dengan pertanyaan dari masalah yang diberikan, sehingga kemampuan berpikir tingkat tinggi siswa masih kurang dalam penyelesaian soal tersebut. Rata-rata yang di dapat dari hasil pra observasi belum mencapai KKM yaitu 68, sedangkan nilai KKM adalah 75, sehingga kemampuan berpikir tingkat siswa tergolong masih rendah. Hasil pra observasi dapat dilihat pada gambar 1 di bawah ini :

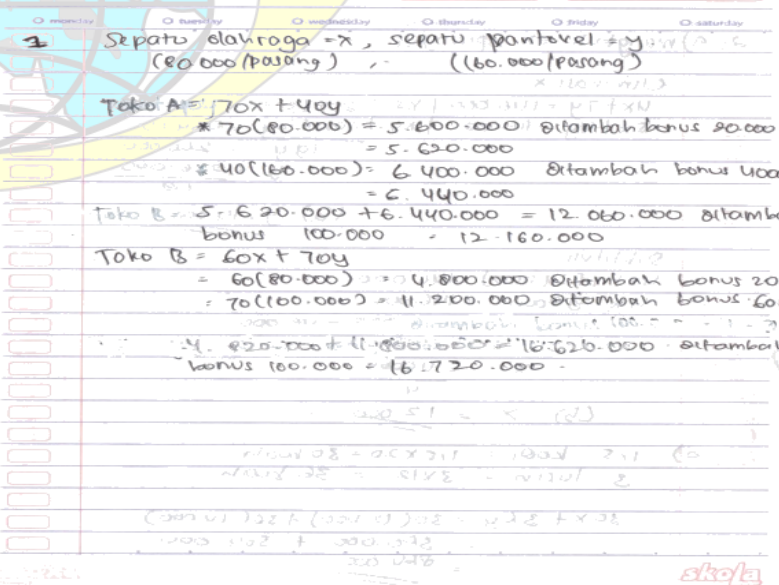

Gambar 1. Gambaran Hasil Pra Obesrvasi HOTS

Dilihat dari hasil pra observasi di atas maka perlu dicari solusinya dan solusi yang dapat dilakukan adalah mencoba menerapkan model, strategi atau pendekatan pembelajaran inovatif yang tidak lagi berpusat pada guru 
(teacher centered) tetapi lebih berpusat pada siswa (student centered). Pembelajaran yang berpusat pada siswa (student centered) adalah pembelajaran yang lebih mengarahkan kepada keaktifan siswa, dan siswa mengkontruksi pengetahuannya sendiri. Di sisi lain, pembelajaran tersebut lebih menekankan apa kebutuhan, minat, bakat, dan kemampuan peserta didik, sehingga pembelajaran akan lebih bermakna. Salah satu model yang berpusat pada siswa (student centered) model pembelajaran problem based learning. Selain itu, model pembelajaran ini direkomendasikan dalam kurikulum 2013.

Salah satu model pembelajaran yang sesuai dengan implementasi kurikulum 2013 dan menuntut keaktifan dan kemampuan siswa adalah model Problem Based Learning (PBL). Problem Based Learning diartikan sebagai model kurikulum yang dirancang menggunakan kehidupan nyata. Problem Based Learningmenekankan pada penggunaan masalah sebagai sarana bagi peserta didik untuk mengembangkan keterampilan HOTS dalam menyelesaikan masalah nyata. Secara umum dengan model problem based learning bertujuan mengenal siswa terhadap sebuah masalah atau kasus yang sesuai dengan materi yang dipelajarinya dan didalamnya siswa di tuntut untuk melakukan kegiatan untuk menyelesaikan permasalahan yang disajikan guru terutama pada materi sistem persamaan linear dua variabel (SPLDV). Model ini merupakan konsep yang melibatkan siswa untuk melatih siswa berpikir matematis tingkat tinggi yang ada didunia nyata sehingga siswa mampu mempelajari pengetahuan yang berkaitan dengan masalah dan sekaligus siswa diharapkan akan memiliki keterampilan berpikir tingkat tinggi.

Menurut Amir (2010), Trianto (2011) Savery (2015) bahwa problem based learning adalah model pembelajaran yang dimulai dengan pemberian masalah, dan masalah yang diberikan biasanya berhubungan dengan duunia nyata atau kontekstual. Dari masalah tersebut secara berkelompok, siswa diminta untuk mengidentifikasi, mempelajari dan mencari sendiri materi terkait masalah yang diberikan dan melaporkan solusi dari masalah tersebut.

Berdasarkan paparan tersebut maka judul penelitian ini adalah "Pengaruh Model Problem Based Learning Terhadap Higher Order Thingking Skills (HOTS) Matematis Siswa Pada Materi Sistem Persamaan Linear Dua Variabel Di Kelas X SMA N 9 Pontianak”. Adapun yang menjadi tujuan penelitian ini adalah untuk mengetahui pengaruh model pembelajaran Problem Based Learning terhadap Higher Order Thingking Skills (HOTS) matematis siswa pada materi SPLDV di kelas X SMA N 9 Pontianak. Adapun tujuan dari beberapa sub masalah tersebut adalah untuk mengetahui : (1) diskripsi Higher Order Thingking Skills (HOTS) matematis siswa sebelum dan sesudah diterapkan model Problem Based Learning pada materi SPLDV di kelas X SMA N 9 pontianak. (2) pengaruh dan besarnya pengaruh model Problem Based Learning terhadap Higher Order Thingking Skills (HOTS) matematis siswa pada materi SPLDV di kelas X SMA Negeri 9 Pontianak.

\section{METODE}

Metode yang digunakan dalam penelitian ini adalah eksperimen. Sugiyono (2013: 107) menyatakan bahwa metode eksperimen merupan metode penelitian yang digunakan untuk mencari pengaruh perlakuan tertentu terhadap yang lain dalam kondisi yang terkendali. Kondisi yang dimaksud dalam penelitian ini adalah pengaruh model problem based learning terhadap higher order thingking skills (HOTS) matematis siswa pada materi SPLDV di kelas X SMA Negeri 9 Pontianak. Bentuk penelitian yang digunakan dalam penelitian ini adalah Pre-Experimental Design. Menurut Sugiyono (2013: 109) dikatakan Pre-Experimental Design karena belum merupakan eksperimen sungguh-sungguh, karena belum terdapat variabel luar (variabel kontrol) yang ikut berpengaruh terhadap terbentuknya variabel terikat.

Rancangan dalam dalam penelitian ini menggunakan One-Group Pretest-Posttest Design, yaitu desain yang hanya menggunakan satu kelompok sampel saja yang 
diberikan tes awal dan tes akhir setelah diberikan perlakuan. Dengan demikian hasil perlakuan dapat diketahui lebih akurat, karena dapat membandingkan keadaan sebelum dengan setelah diberikan perlakuan.

Populasi dalam penelitian ini adalah siswa kelas $\mathrm{X}$ MIA SMA Negeri 9 Pontianak yang terdiri dari tiga kelas yaitu X MIA 1, X MIA 2, X MIA 3 yang berjumlah 108 siswa. Penentuan sampel pada penelitian ini dilakukan dengan menggunakan teknik Cluster Random Sampling, yaitu pengambilan anggota sampel dari populasi yang dilakukan dengan merandom kelas.

Adapun langkah-langkah pengambilan sampel dalam penelitian ini adalah sebagai berikut: Meminta hasil ulangan harian kelas X SMA Negeri 9 pontianak kepada guru bidang studi pendidikan matematika. Selanjutnya data tersebut diuji homogenitas dengan menggunakan uji bartlett untuk mengetahui apakah ketiga kelas tersebut homogen atau tidak. Dari hasil perhitungan diketahui bahwa ketiga kelas tersebut adalah homogen. Pengambilan sampel dilakukan dengan cara mengkode setiap kelas dan menulisnya ke dalam kertas kecil yang digulung, kemudian mengambil secara acak dengan pengundian yang dilakukan oleh peneliti dan pengambilan itu didapat kelas X MIA 2 yang ditetapkan sebagai kelas eksperimen.

Teknik pengumpulan data yang digunakan pada penelitian ini adalah teknik pengukuran. Menurut Budiyono (2011: 30) menyatakan bahwa pengukuran adalah sekumpul cara untuk memberikan bilangan untuk menyatakan objek, kemampuan, atribut atau perilaku. Didalam penelitian ini pengukuran digunakan untuk mengumpulkan data mengenai Higher Order Thingking Skills (HOTS) yang diterapkan dengan model Problem Based Learning pada materi sistem persamaan linear dua variabel. Agar data yang dikumpulkan lebih akurat, maka peneliti menggunakan alat bantu untuk mengumpulkan data atau yang sering disebut dengan instrumen penelitian. Alat pengumpulan data yang digunakan dalam penelitian ini adalah berupa tes Higher Order Thingking Skills (HOTS). Menurut Nurhadi dan Suwardi (2010: 29) mengatakan bahwa tes adalah suatu cara dalam rangka melaksanakan kegiatan evaluasi, yang berisikan serangkaian tugas untuk dikerjakan atau dijawab oleh peserta didik yang memiliki jawaban benar atau salah.

Tes bertujuan untuk mengumpulkan informasi tentang kemampuan, penguasaan dan pemahaman terhadap materi dan selanjutnya diberikan skor atau nilai. Tes tersebut dilakukan pada saat sebelum dan setelah diberikan perlakuan model Problem Based Learning untuk mengetahui Higher Order Thingking Skills (HOTS) dalam bentuk soal uraian yang diberikan pada kelas eskperimen.

Teknik analisis data yang digunakan dalam penelitian ini menggunakana statistik deskriptif dan inferensial. Untuk mengetahui tujuan penelitian pertama menggunakan statistik deskriptif, sedangkan untuk mengetahui tujuan penelitian ke dua menggunakan statistik inferensial, uji t. tetapi sebelum dilakukukan uji t terlebuh dahulu dilakukan uji prasyarat uji t yaitu data harus berdistribusi normal. Uji normalitas dalam penelitian ini menggunakan uji statistik Chi-kuadrat, sedangkan uji t menggunakan uji-t satu kelompok.

\section{HASIL DAN PEMBAHASAN}

\section{Deskripsi Data}

Dari hasil pengumpulan data dengan menggunakan tes uraian di SMA Negeri 9 pontianak setelah dikoreksi sesuai dengan pedoman penskoran dan diberinilai, kemudian diperoleh nilai rata-rata siswa dari pretest dan posttest. Dilihat dari hasil pretest dan posttest Higher Order Thingking Skills matematis atau kemampuan berpikir tingkat tinggi matematis siswa kelas X SMA Negeri 9 Pontianak pada materi SPLDV, dapat dikatakan memiliki Higher Order Thingking Skills matematis sangat baik jika nilainya mencapai $\geq 80$, baik jika $80>$ HOTS $\geq 60$, cukup jika nilai $60>$ HOTS $\geq 40$, dan kurang jika HOTS $<40$.

Dari hasil penelitian menunjukkan bahwa sebelum diberikan perlakuan nilai rata-rata pretest sebesar 44 . Dari 36 siswa, Higher Order Thingking Skills (HOTS) yang dimiliki oleh siswa dengan kriteria kurang berjumlah 17 siswa, kriteria cukup berjumlah 16 siswa, 
kriteria baik berjumlah 3 siswa, dan tidak ada siswa yang memiliki kriteria HOTS sangat baik. Setelah melakukan pretest, siswa mendapatkan perlakuan dengan model pembelajaran Problem Based Learning. Setelah diberikan perlakuan, nilai rata-rata HOTS sebesar 73. Dari 36 siswa, Higher Order Thingking Skills (HOTS) yang dimiliki oleh siswa dengan kriteria cukup berjumlah 2 siswa, kriteria baik berjumlah 26 siswa, kriteria sangat baik berjumlah 8 siswa, dan tidak ada siswa yang memiliki kriteria kurang, artinya semua nilai siswa di atas 40. Oleh sebab itu, bisa diduga bahwa model pembelajaran Problem Based Learning berpengaruh terhadap Higher Order Thingking Skills. Tetapi, dugaan ini perlu dibuktikan dengan uji statistik yang akan dilakukan pada analisis data berikutnya.

\section{Analisis Data}

\section{Uji normalitas}

Hasil uji normalitas pretest diperoleh $\chi_{\text {hitung }}^{2}$ sebesar 3,26 sedangkan uji normalitas posttest diperoleh $\chi_{\text {hitung }}^{2}$ sebesar 6,38 dengan $\chi_{\text {tabel }}^{2}(\alpha=5 \%$ dan $\mathrm{dk}=3)$ sebesar 7,815 . Karena $\chi_{\text {hitung }}^{2} \leqslant \chi_{\text {tabel }}^{2}$, maka data hasil pretest dan posttest berdistribusi normal.

\section{Uji hipotesis (uji-t)}

Berdasarkan uji-t, diperoleh $t_{\text {hitung }}$ sebesar 11,64 dan $t_{\text {tabel }}(\alpha=5 \%$ dan $d k=35)$ sebesar 1,6896 . Karena $t_{\text {hitung }}(11,64)>t_{\text {tabel }}(1,6896$, maka $H$ ditolak dan berakibat $\mathrm{H}_{\mathrm{a}}$ diterima, artinya terdapat pengaruh model Problem Based Learning terhadap Higher Order Thingking Skils matematis siswa pada materi SPLDV di kelas X SMA Negeri 9 Pontianak".

\section{Effect size}

Berdasarkan perhitungan effect size, diperoleh besar pengaruh model Problem Based Learning terhadap Higher Order Thingking Skills matematis siswa pada materi SPLDV di kelas X SMA Negeri 9 Pontianak sebesar 2,5 dengan kriteria tinggi.
Ada pun hasil pengolahan nilai pretest dan posttest Higher Order Thingking Skills dapat dilihat pada tabel 1 berikut :

Tabel 1. Hasil Pengolahan Nilai Pretest dan Posttest Siswa

\begin{tabular}{|c|c|c|}
\hline Keterangan & Pretest & Posttest \\
\hline Rata-rata $(\overline{\boldsymbol{x}})$ & 44 & 73 \\
\hline Standar deviasi $(\boldsymbol{S D})$ & 11.6 & 9.51 \\
\hline Uji normalitas $\left(\boldsymbol{\chi}^{2}\right)$ & 3.26 & 6.38 \\
\hline & \multicolumn{2}{|c|}{ Pre-Posttest } \\
\hline Uji hipotesis $(\boldsymbol{t})$ & \multicolumn{2}{|c|}{11,64} \\
\hline Effect size $\left(\boldsymbol{E}_{S}\right)$ & \multicolumn{2}{|c|}{2,5} \\
\hline
\end{tabular}

Dari hasil pengolahan nilai pretest dan posttest siswa diperoleh rata-rata nilai pretest sebesar 44 dan posttest 73, standar deviasi pretest sebesar 11,6 dan posttest 9,51. Untuk uji hipotesis pre-posttest sebesar 11,64 dan effect size nya sebesar 2,5 .

\section{Pembahasan}

Penelitian ini dilakukan di kelas X MIA 2 SMA Negeri 9 Pontianak tahun ajaran 2018/2019. Pada kelas ini terdapat 36 siswa yang dijadikan sebagai sampel dalam penelitian. Tahapan penelitian ini yaitu, pemberian tes awal (pretest), pemberian perlakukan (treatment), dan pemberian tes akhir (posttest). Proses pembelajaran di kelas dilakukan sebanyak dua kali pertemuan. Setiap pertemuan berlangsung selama 2 x 45 menit dengan menggunakan model Problem Based Learning. Dalam proses pembelajaran siswa dituntun untuk memiliki Higher Order Thingking Skills (HOTS).

Pada pertemuan pertama, peneliti memberikan pretest (tes awal) untuk mengetahui bagaimana kemampuan awal Higher Order Thingking Skills (HOTS). Pada pertemuan kedua, peneliti meminta siswa untuk mengungkapkan kembali pemahaman mereka yang berkaitan dengan masalah yang di berikan, kemudian peneliti juga mengajukan pertanyaan untuk mengetahui dan menggali pengetahuan awal siswa yang berkaitan dengan masalah. Selanjutnya peneliti membentuk kelompok belajar yang masing-masing terdiri dari 6 orang siswa yang heterogen. Dalam tahap ini sikap kerja sama setiap anggota kelompok sangat diperlukan untuk 
menyelesaikan masalah yang diberikan oleh peneliti. Selain membimbing dan membantu siswa memahami masalah, peneliti juga mengajukan pertanyaan agar siswa dapat berpikir untuk menyelesaikan masalah.

Pada pertemuan ketiga, peneliti memberikan kesempatan kepada kelompok-kelompok tersebut untuk mempresentasikan hasil kerja kelompoknya di depan kelas. Presentasi ini merupakan bentuk pengembangan sikap agar siswa berani menyampaikan pendapat di depan kelas dan dapat berperan aktif di kelas. Pada pertemuan selanjutnya, peneliti memberikan posttest (tes akhir). Tahap-tahap pembelajaran tersebut pada prinsipnya membentuk prilaku disiplin, aktif, kerja sama, dan rasa tanggung jawab.

Sebelum diberikan perlakuan (treatment) rerata nilai pretest siswa adalah 44. Dari 36 siswa, yang memiliki Higher Order Thingking Skills (HOTS) dengan kriteria kurang berjumlah 17 siswa, dengan kriteria cukup berjumlah 16 siswa, dan dengan kriteria baik berjumlah 3 siswa. Setelah melakukan pretest, siswa mendapatkan perlakuan (treatment) yang diterapkan dengan model Problem Based Learning. Setelah diberikan perlakuan (treatment) rerata nilai posttest sebesar 73. Dari 36 siswa, yang memiliki Higher Order Thingking Skills (HOTS) dengan kriteria cukup berjumlah 2 siswa, dengan kriteria baik berjumlah 26 siswa, dan dengan kriteria sangat baik berjumlah 8 siswa.

Dari hasil perhitungan olah data dan uji hipotesis dengan menggunakan uji t diperoleh kesimpulan bahwa $\mathrm{H}_{0}$ ditolak maka $\mathrm{H}_{\mathrm{a}}$ diterima, artinya terdapat pengaruh model Problem Based Learning terhadap Higher Order Thingking Skills (HOTS) matematis siswa pada materi sistem persamaan linear dua variabel di kelas X SMA Negeri 9 Pontianak, sedangkan untuk hasil perhitunggan effect size nya yaitu sebesar 2,5 maka dapat disimpulkan bahwa besar pengaruh model Problem Based Learning terhadap Higher Order Thingking Skills (HOTS) sebesar 2,5 dengan kriteria tinggi. Hasil penelitain ini sesuai dengan pendapat Hmelo-Silver, (2004) bahwa model Problem Based Learning sangat cocok untuk membantu siswa menjadi pembelajar aktif karena menempatkan pembelajaran dalam masalah dunia nyata dan membuat siswa bertanggung jawab atas pembelajaran mereka. Dalam model Problem Based Learning, siswa akan mengkontruksi pengetahuan mereka, melalui diskusi siswa akan menemukan solusi penyelesaian dari masalah yang diajukan oleh guru sebelumnya.

Hasil penelitian ini juga sesuai dengan hasil penelitian Mutmainah, Kusmayadi \& Riyadi (2015) bahwa model Problem Based Learning (PBL) menghasilkan kemampuan berpikir tingkat tinggi lebih baik dari model pembelajaran Group Investigation (GI) dan model pembelajaran langsung, Herman (2007) dalam penelitiannya menyimpulkan bahwa model Problem Based Learning secara signifikan lebih baik daripada pembelajaran konvensional dalam meningkatkan kemampuan berpikir matematis tingkat tinggi siswa, dan hasil penelitian Prasetyani, dkk. (2016) dan Mayasari \& Adawiyah (2016) yang menyimpulkan bahwa pembelajaran berbasis masalah atau model Problem Based Learning dapat meningkatkan dan berpengaruh terhadap Higher Order Thingking Skills (HOTS).

\section{PENUTUP}

\section{Simpulan}

Berdasarkan analisis terhadap data hasil penelitian yang dilakukan melalui penelitian eksperimen dengan model Problem Based Learning terhadap Higher Order Thingking Skills (HOTS) matematis siswa pada materi sistem persamaan linear dua variabel di kelas X SMA Negeri 9 Pontianak maka dapat disimpulkan secara umum bahwa model pembelajaran Problem Based Learning berpengaruh yang signifikan terhadap Higher Order Thingking Skills (HOTS) matematis siswa pada materi sistem persamaan linear dua variabel di kelas $\mathrm{X}$ SMA Negeri 9 Pontianak. Adapun kesimpulan secara terperinci dihasilkan sebagai berikut: (1) Higher Order Thingking Skills (HOTS) matematis siswa sebelum diterapkan model Problem Based Learning pada materi sistem persamaan linear dua variabel di kelas X SMA Negeri 9 Pontianak secara keseluruhan dapat dilihat dari nilai rata-rata Higher Order Thingking Skills (HOTS) 
matematis siswa tergolong cukup. (2) Higher Order Thingking Skills (HOTS) matematis siswa setelah diterapkan model Problem Based Learning pada materi sistem persamaan linear dua variabel di kelas X SMA Negeri 9 Pontianak secara keseluruhan dapat dilihat dari nilai rata-rata Higher Order Thingking Skills (HOTS) matematis siswa tergolong baik. (3) Terdapat pengaruh yang signifikan model Problem Based Learning terhadap

\section{DAFTAR PUSTAKA}

Amir, M. T. (2010). Inovasi Pendidikan Melalui Problem Based Learning. Jakarta: Kencana Prenada Media Group.

Ayuningtias, N. (2013). Proses Penyelesaian Soal Higher Order Thinking Materi Aljabar Siswa SMP Ditinjau Berdasarkan Kemampuan Matematika Siswa. MATHEdunesa, 2(2).

Budiyono. (2011). Penilaian Hasil Belajar. Surakarta: UNS PRESS.

Herman, T. (2007). Pembelajaran berbasis masalah untuk meningkatkan kemampuan berpikir matematis tingkat tinggi siswa sekolah menengah pertama. Jurnal Educationist, 1(1), 47-56.

Hmelo-Silver, C. E. (2004). Problem-based learning: What and how do students learn?. Educational psychology review, 16(3), 235-266.

Krathwohl, D. R. (2002). A revision of Bloom's taxonomy: An overview. Theory into practice, 41(4), 212-218

Mayasari, R., \& Adawiyah, R. (2016). Pengaruh model pembelajaran berdasarkan masalah pada pembelajaran biologi terhadap hasil belajar dan keterampilan berpikir tingkat tinggi di SMA. Jurnal Pendidikan Biologi Indonesia, 1(3).

Mutmainah, S., Kusmayadi, T. A., \& Riyadi, R. (2015). Eksperimentasi Model Problem Based Learning (PBL) Dan Group Investigation (GI) Ditinjau Dari Kategori Kecerdasan Emosional Peserta Didik Terhadap Kemampuan Berpikir Matematis Tingkat
Higher Order Thingking Skills (HOTS) matematis siswa pada materi sistem persamaan linear dua variabel di kelas X SMA Negeri 9 Pontianak. (4) Besar pengaruh model Problem Based Learning terhadap Higher Order Thingking Skills (HOTS) matematis siswa pada materi sistem persamaan linear dua variabel di kelas X SMA Negeri 9 Pontianak dengan kriteria tinggi.

Tinggi Kelas VII SMP Negeri Se-kabupaten Sragen. Jurnal Pembelajaran Matematika, 3(8).

Nurhadi., \& Suwardi. (2010). Evaluasi Pembelajaran yang Efektif dan Menyenangkan. Jakarta: Multi Kreasi Satudelapan.

Prasetyani, E., Hartono, Y., \& Susanti, E. (2016). Kemampuan Berpikir Tingkat Tinggi Siswa Kelas XI Dalam Pembelajaran Trigonometri Berbasis Masalah Di Sma Negeri 18 Palembang. Jurnal Gantang, 1(1), 34-44.

Savery, J. R. (2015). Overview of problem-based learning: Definitions and distinctions. Essential readings in problem-based learning: Exploring and extending the legacy of Howard S. Barrows, 9, 5-15.

Trianto. (2011). Model-Model Pembelajaran Inovatif Berorientasi Konstruktifis. Jakarta: Prestasi Pustaka. 
Hodiyanto: Pengaruh Model Problem Based Learning terhadap Higher Order Thingking Skills (HOTS) Matematis Siswa

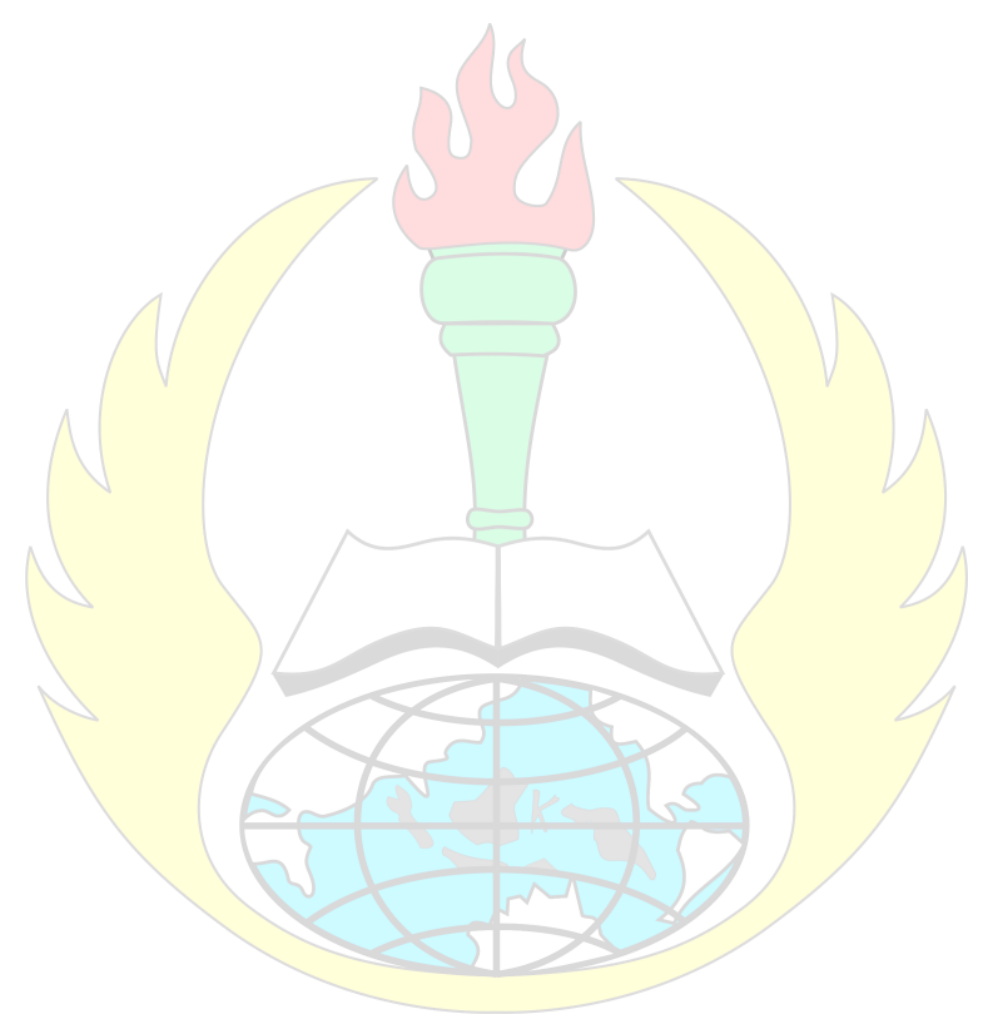

